\title{
ANALISIS DAN IMPLEMENTASI REPORTING SERVICE PADA APLIKASI ABSENSI PNS MENGGUNAKAN SSRS
}

\author{
Jashinta Anggriana Putri ${ }^{1}$, Nur Fauzi Soelaiman ${ }^{1}$ \\ ${ }^{1}$ Politeknik Negeri Jakarta \\ Jl. Prof. Dr. G.A Siwabessy, Kampus Baru UI, Beji, Kukusan, Beji, Kota Depok, Jawa Barat, Indonesia. \\ anggriana.jashinta@gmail.com,fauzi@pnj.ac.id
}

\begin{abstract}
Abstrak - Absensi adalah daftar kehadiran pegawai/siswa, yang berisi jam dating, jam pulang, serta alasan/keterangan kehadiran pegawai. Absensi adalah suatu cara untuk mengetahui sejauh mana tingkat kedisiplin kehadiran pegawai dalam bekerja. Sistem absensi yang masih menggunakan sistem manual, proses pencatatan kehadiran pegawai dapat menimbulkan beberapa masalah, kemungkinan terjadinya kesalahan ataupun hambatan dalam membuat rekapitulasi absensi menjadi besar dan pengawasan kedisiplinan pegawai menjadi tidak optimal. Penggunaan Reporting Service dengan SSRS merupakan suatu solusi strategis terhadap kendala perekapan absensi tesebut sehingga pengawasan terhadap kedisiplinan tetap terjaga terutama. Reporting service adalah sebuah platform pelaporan berbasis server yang menyediakan fungsionalitas pelaporan komprehensif dari dan untuk berbagai sumber data. Dengan aplikasi absensi yang telah menggunakan teknologi reporting service ini maka pimpinan instansi pun dapat dengan mudah melakukan pengawasan kedisiplinan dengan melihat rekapan absensi yang sistematis dan otomatis sebagai bahan penunjang analisis kendisiplinan pegawainya.
\end{abstract}

Keywords-Reporting Service, SSRS, Absensi.

\section{PENDAHULUAN}

Absensi adalah suatu proses pencatatan kehadiran yang berisi mulai dari jam datang, jam pulang, hingga alasan atau keterangan ketidakhadiran. Absensi merupakan salah satu bentuk pengawasan atau kontrol terhadap tingkat kedisiplin kehadiran pegawai di dalam suatu instansi.

Dalam pengawasan dan kontrol kedisiplinan pegawai terutama Pegawai Negeri Sipil (PNS) tersebut, maka pemerintah telah mengantisipasi dan mengaturnya dalam suatu peraturan yaitu Peraturan Pemerintah (PP) Nomor 53 Tahun 2010 [1] tentang disiplin Pegawai Negeri Sipil. Peraturan Pemerintah (PP) Nomor 53 Tahun 2010 adalah peraturan yang mengatur tentang kewajiban, larangan, sanksi apabila kewajiban seorang pegawai tidak ditaati atau dilanggar.

Namun penerapan dari peraturan tersebut dalam suatu instansi tentunya tidak luput dari peranan seorang pemimpinnya. Dalam kondisi tersebut dimana pengawasan dari seorang pemimpin sangat diperlukan untuk mengurangi dan mencegah pelanggaran atau kesalahan pegawainya, maka diperlukankalah suatu sistem yang digunakan untuk memantau kinerja pegawai yang salah satunya adalah sistem absensi

Kegiatan absensi yang berjalan hingga saat ini masih kebanyakan menggunakan sistem manual, dengan cara mencatat kehadiran pegawai di dalam sebuah buku bahkan di selembar kertas absensi. Akibatnya kemungkinan terjadinya kesalahan ataupun hambatan dalam membuat rekapitulasi absensi menjadi besar dan pengawasan kedisiplinan pegawai menjadi tidak optimal.
Pengawasan merupakan proses pemantauan, memeriksa, dan mengevaluasi yang dilaksanakan oleh pimpinan unit oraganisasi kerja terhadap sumber-sumber kerja untuk diperbaiki atau disarankan oleh pimpinan yang berwanang pada jenjang yang lebih tinggi demi tujuan yang telah dirumuskan [2].

Untuk meminimalisir kemungkinan terjadinya kendala serta hambatan yang terjadi dalam rekaptulasi absensi tersebut serta untuk mempermudah seorang pemimpin instansi untuk melakukan pengawasan kedisiplinan pegawainya, maka pengaplikasian reporting service merupakan solusi yang tepat. Reporting service adalah sebuah platform pelaporan berbasis server yang menyediakan fungsionalitas pelaporan komprehensif dari dan untuk berbagai sumber data. Reporting service merupakan solusi yang tepat untuk membuat, menerbitkan, dan mengelola laporan, kemudian mengantarkannya ke pengguna yang tepat dengan cara yang berbeda, entah itu yang dalam web browser, dalam perangkat seluler, atau sebagai email [3].

Berdasarkan latar belakang yang telah diuraikan tersebut, maka permasalahan yang akan dibahas adalah bagaimana mengaplikasikan reporting service dalam merekaptulasikan absensi yang hingga saat ini masih menggunakan sistem manual serta bagaimana hasil dari rekaptulasi absensi yang menggunakan reporting service dapat digunakan oleh pemimpin instansi sebagai alat pengawasan dan analisis kedisiplinan pegawai yang dipimpinnya. 


\section{TINJAUAN PUSTAKA}

\section{A. Absensi}

Menurut Kamus Besar Bahasa Indonesia [4], absen adalah tidak masuknya seorang siswa/pegawai pada saat hari masuk /kerja karena sakit, izin, alpa, atau cuti. Sedangkan absensi adalah daftar kehadiran pegawai/siswa, yang berisi jam dating, jam pulang, serta alasan/keterangan kehadiran pegawai. Absensi adalah suatu cara untuk mengetahui sejauh mana tingkat kedisiplin kehadiran pegawai dalam bekerja.

Pengaturan tentang absensi, pada dasarnya harus jelas dan tegas dalam menyebutkan definisi tidak masuk kerja yang dimaksud. Selanjutnya, masing-masing alasan absen tersebut diberi bobot nilai negatif, sesuai ketentuan yang telah digariskan [5].

\section{B. Microsoft SQL Server 2016}

Microsoft SQL Server adalah sistem manajemen basis data yang digunakan untuk menyimpan berbagai jenis data, dan telah didukung teknologi cloud. Microsoft SQL Server menyediakan seperangkat alat untuk mengekstrak data dari berbagai perangkat atau sumber, bahkan di pusat data.

Menurut Ben-Gan [6], Structured Query Language (SQL) adalah bahasa standar yang digunakan untuk query dan mengelola data dalam relasi sistem manajemen database (RDBMSs). Selain itu menurut LeBlanc [7], dengan menggunakan bahasa query Microsoft SQL Server yang disebut T-SQL (Transact-SQL), pengguna dapat memanipulasi query data yang memungkinkan untuk dimofikasi serta diakses data sesuai permintaan. Adapaun beberapa layanan yang disediakan dalam platform Microsoft SQL Server yang diantaranya adalah Database Engine, Integration Services (SSIS, SQL Server Integration Services), SQL Agent, Reporting Services (SSRS, SQL Server Reporting Services), dan Analysis Services (SSAS, SQL Server Analysis Services).

\section{Reporting Service}

Reporting Service adalah platform pelaporan berbasis server yang menyediakan fungsionalitas pelaporan komprehensif untuk berbagai sumber data. Reporting Service mencakup seperangkat alat lengkap untuk membuat, mengelola, dan mendistribusikan laporan, serta API yang memungkinkan pengembang untuk mengintegrasikan data dan laporan dalam aplikasi.

Dengan Reporting Service, pengembang dapat membuat laporan data yang interaktif seperti tabular atau bentuk lainnya dari sumber data relasional, multidimensi, atau XML. Laporan dapat pula berupa visualisasi data dalam bentuk grafik, peta, dan sebgainya. Selain dari sisi pengembang, pengguna juga dapat mempublikasikan laporan, penjadwalan laporan, serta mengakses laporan sesuai permintaan.

\section{SQL Server Reporting Service (SSRS)}

SQL Server Reporting Service (SSRS) merupakan tools pelapooran (reporting) yang dikembangkan oleh Microsoft. SSRS kompatibel dengan berbagai sumber data diantaranya SQL Server, SQL Azure, SSAS model multidimensional dan model tabular, Parallel Datawarehouse, OLE DB, ODBC, serta SharePoint List. Laporan dapat dibuat menggunakan Visual Studio atau SQL Data Tools Business Intelligence (SSDT-BI) yang menyediakan antarmuka secara drag and drop, yang nantinya menghasilkan sebuah berkas Report Definition Language (RDL) berdasarkan XML.

SSRS menyediakan Report Designer, Report Builder, Power View, Report Server serta Report Manager yang mana digunakan untuk mengunggah berkas RDL yang oleh pengguna dapat digunakan sebagai bahan analisis kebutuhan bisnis. Pelaporan dapat dilakukan dengan pendjawalan serta dapat diditribusikan melalui portal, email, dan dapat juga diubah kedalam bentuk HTML, PDF, Excel, berbagai macam tipe gambar (TIFF, BMP, GIF, JPEG, PNG), serta format Microsoft Word. SSRS adalah salah satu alat pelaporan (reporting-tools) paling handal selama beberapa tahun terakhir karena tersedia berbagi fitur yang dapat digunakan untuk membuat laporan yang sesuai dengan berbagai macam kebutuhan pengguna [8].

\section{METODE PENELITIAN}

\section{A. Rapid Application Development}

Metode Rapid Application Development adalah metode yang digunakan dalam pembuatan aplikasi sistem absensi mennggunak reporting service SSRS. Rapid Application Development (RAD) adalah sebuah metode pengembangan system dengan pendekatan prototyping yang yang dirancang untuk mengasilkan sistem yang berkualitas tinggi dengan waktu yang relatif cepat serta biaya yang cukup rendah. Dalam metode RAD yang berpusat pada protoype, tahap analisis, perancangan, pembuatan serta testing menjadi sebuah siklus pengembangan yang berulang dan singkat.

RAD sering direalisasikan melalui pendekatan prototyping. Para aktor dapat memberikan respon terhadap prototype tersebut dan memberikan masukan untuk spesifikasi lebih lanjut dari sytem yang akan dibangun [9]. Metode RAD mempunyai beberapa tahapan seperti yang terlihat pada Gambar 1.

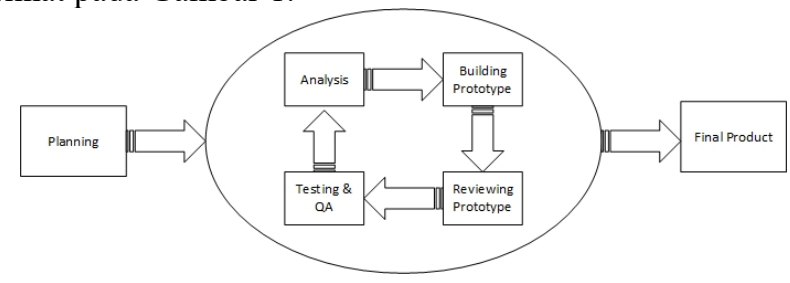

Gbr 1 Ilustrasi dari Metode RAD 


\section{IV.HASIL DAN PEMBAHASAN}

\section{A. Implementasi Reporting Service Menggunakan SSRS}

Pada Gambar 2 merupakan ilustrasi dari mana asal data, kemana tujuan data keluar, serta proses apa yang menghasilkan data dalam implementasi reporting service menggunakan SSRS.

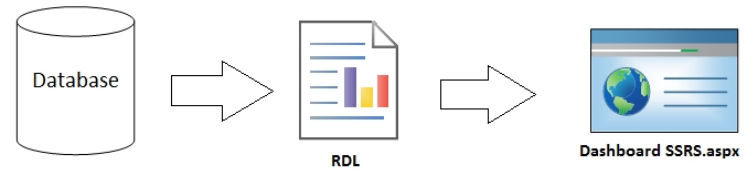

Gbr 2 Ilustrasi dari tahapan proses implementasi reporting service menggunakan SSRS

Dari Gambar 2 diatas, maka dapat dikonsepkan bahwa proses yang terjadi dalam pengimplementasian reporting service dimulai dari penyimpanan data yaitu di dalam sebuah database. Proses berikutnya adalah dimana data yang telah disimpan di dalam database tersebut dikirimkan untuk menjadi input data dari sebuah laporan (report) yang akan diolah senhingga menghasilkan sebuah berkas Report Definition Language (RDL) yang mana memuat data dari database. Proses yang berjalan selanjutanya adalah berkas RDL yang telah dibuat tersebut di-deploy sehingga menghasilkan ouput berupa sebuah halaman aspx yang merupakan dashboard dari SSRS.

Secara teknis, pengimplementasian dimulai dengan membuat database, sebagai tempat penyimpanan data. Database yang digunakan dalam aplikasi absensi adalah database dari Microsoft SQL Server 2016. Salah satu kumpulan dari kode (query) dalam rancangan database tersebut ditunjukkan dalam Gambar 3.

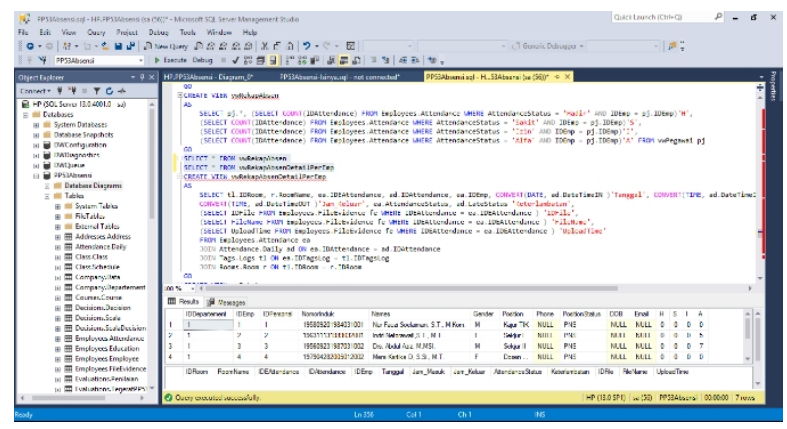

Gbr 3 Queries SQL Server 2016

Pada Gambar 3 ditunjukan query dari SQL yang digunakan adalah SELECT * FROM vwRekapAbsen yang mana merupakan query untuk menampilkan dar tabeli rekapan absen semua pegawai. Kolom dari tabel vwRekapAbsen beserta penjelasannya dapat dilihat pada Tabel 1.
TABEL I

KOLOM DARI VWREKAPABSEN

\begin{tabular}{|c|c|}
\hline IDDepartment & $\begin{array}{l}\text { ID dari Department Pegawai yang } \\
\text { mana menjadi primary key dari tabel } \\
\text { department }\end{array}$ \\
\hline IDEmp & $\begin{array}{l}\text { ID dari Employee dalam database } \\
\text { yang mana menjadi primary key dari } \\
\text { tabel employee }\end{array}$ \\
\hline IDPersonal & $\begin{array}{l}\text { ID dari Personalia Employee yang } \\
\text { mana menjadi primary key dari tabel } \\
\text { personalia employee }\end{array}$ \\
\hline NomorInduk & $\begin{array}{l}\text { Nomor Induk dari Pegawai/Nomor } \\
\text { Identitas Kepegawaian }\end{array}$ \\
\hline Names & Nama dari Pegawai \\
\hline Gender & Jenis Kelamin dari Pegawai \\
\hline Position & Posisi pegawai dalam instansi \\
\hline Phone & Nomor telepon dari pegawai \\
\hline PositionStatus & Status dari pegawai dalam instansi \\
\hline DOB & Tempat tanggal lahir pegawai \\
\hline Email & Email dari pegawai \\
\hline $\mathrm{H}$ & $\begin{array}{lrrr}\text { Jumlah rekapan } & \text { banyak } & \text { hari } \\
\text { kehadiran pegawai } & & \\
\end{array}$ \\
\hline $\mathrm{S}$ & $\begin{array}{l}\text { Jumlah rekapan banyaknya hari sakit } \\
\text { pegawai }\end{array}$ \\
\hline I & $\begin{array}{l}\text { Jumlah rekapan banyaknya hari izin } \\
\text { pegawai }\end{array}$ \\
\hline A & $\begin{array}{l}\text { Jumlah rekapan banyaknya hari } \\
\text { pegawai tidak masuk tanpa alasan. }\end{array}$ \\
\hline
\end{tabular}

Langkah selanjutnnya ketika database berhasil dibangun adalah merancang sebuah Report Definition Language (RDL). Dalam tahap ini RDL akan dirancang menggunakan perangkat lunak Visual Studio 2015. Hal ini dikarenakan SSRS yang mana merupakan sebuah tools yang dikembangkan oleh Microsoft, maka SSRS juga hanya dapat dikembangkan oleh product Microsoft. Dalam Visual Studio, RDL akan dirancang dengan menggunakan Reporting Services dengan template Report Server Project seperti ditampilkan pada Gambar 4.

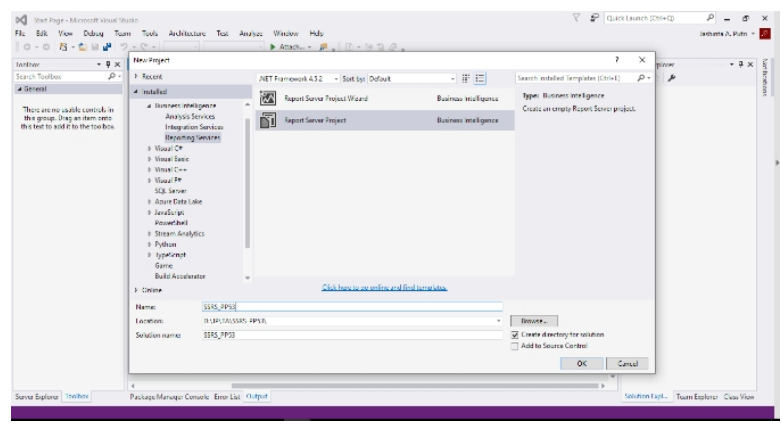

Gbr 4 Report Server Project dalam Visual Studio

Dalam Gambar 4 ditunjukkan bahwa Reporting Service adalah bagian dari Business Intelligence Project dalam Visual Studio 2015. Selain Reporting Service (SSRS), BI 
tools lainnya yang merupakan bagian dari Microsoft adalah Analysis Servive (SSAS), dan Integration Service (SSIS).

Setelah tahap pembuatan proyek baru dengan template Report Server Project selesai, biasanya Visual Studio langsung menyuguhkan sebuah jendela Report Wizard yang digunakan untuk mengkonfigurasi sumber data yang akan digunakan, query dari sumber data, tipe laporan yang akan dibuat, desain serta format dari laporan sehingga nantinya akan menghasilkan sebuah RDL. Namun untuk mendapatkan hasil laporan yang sesuai dengan kebutuhan analisa maka akan lebih baik jika pembuatan dilakukan dengan tahapan manual.

Tahapan secara manual tersebut diawali dengan mengklik kanan folder laporan dan memilih add new item dan memilih Report seperti yang ditampilkan pada Gambar 5.

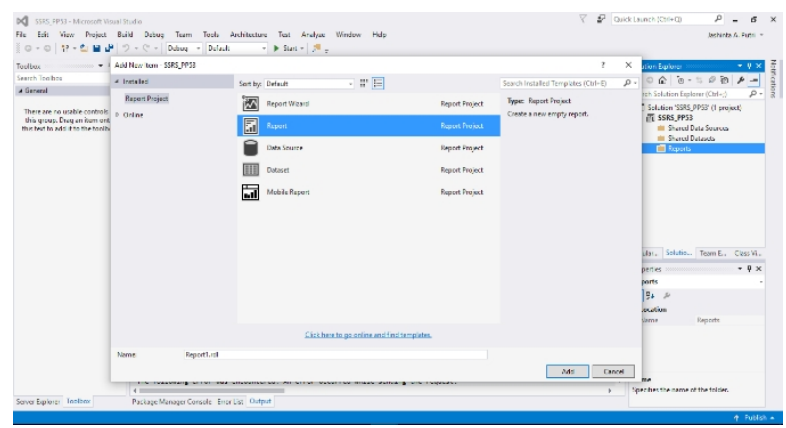

Gbr 5 Add new Report

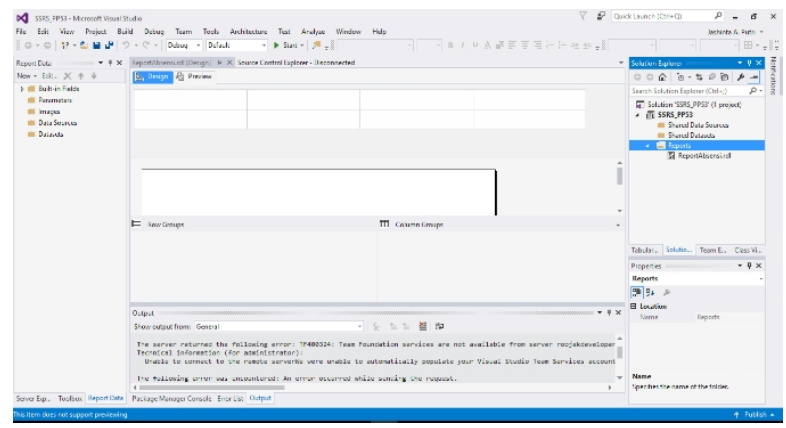

Gbr 6 Blank RDL File

Pada Gambar 6 tampak terlihat Report yang baru saja ditambahkan berekstensi '.rdl' yang merupakan layout laporan yang akan di-deploy nantinya. Untuk mengisi report yang baru saja ditambahkan tersebut, maka diperlukan konfigurasi data source dimana merupakan asal data dari konten yang mengisi file rdl. Maka langkah selanjutnya yang akan dilakukan adalah mengkonfigurasi data source serta pemilihan database seperti yang tampak pada Gambar 7.

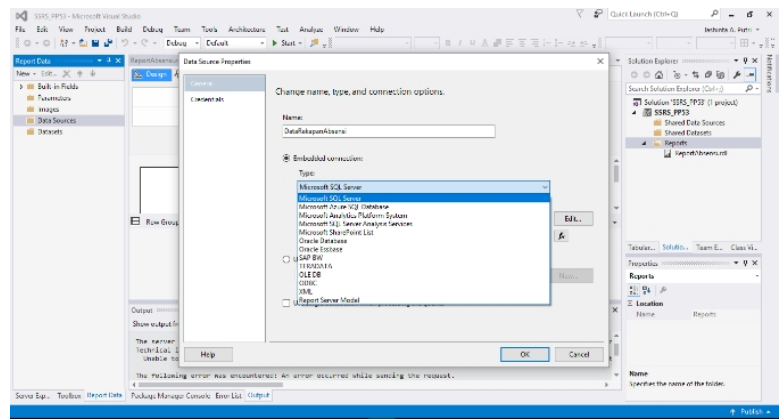

Gbr 7 Konfigurasi Data Source I

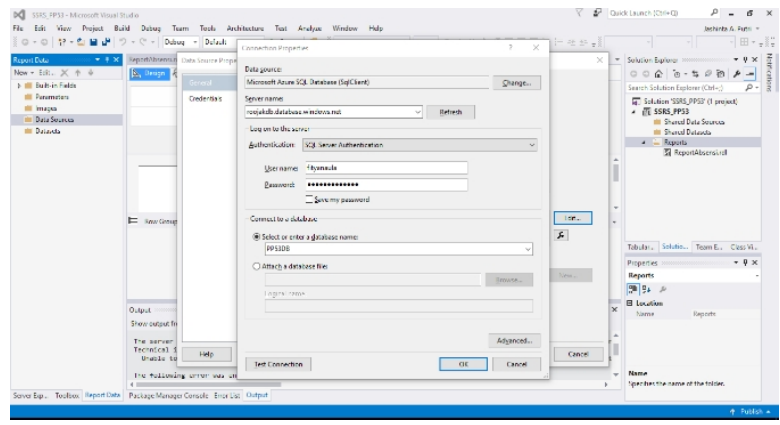

Gbr 8 Konfigurasi Data Source II

Tampak pada Gambar 8 terdapat banyak pilihan sumber data (data source) karena memang SSRS merupakan tools yang kompatibel dengan berbagai sumber data (data source) diantaranya SQL Server, SQL Azure, SharePoint List, OLE DB, dan sebagainya. Dikarenakan database yang digunakan untuk membangun aplikasi absensi adalah dari Microsoft SQL Server 2016, maka pilihan tipe data source akan tertuju pada Microsoft SQL Server.

Setelah selesai melakukan konfigurasi data source maka langkah selankutnya adalah mengkonfigurasi data set yang akan ditampilkan seperti yang ada pada Gambar 9.

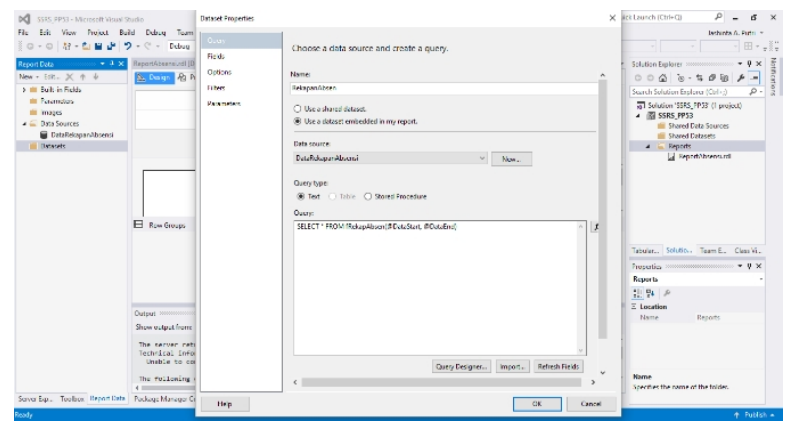

Gbr 9 Konfigurasi Detail Data Set

Kembali kepada tujuan utama dari pembuatan aplikasi absensi menggunakan reporting service yakni untuk meminimalisir kemungkinan terjadinya kendala serta hambatan yang terjadi dalam rekaptulasi absensi, maka tentunya konten RDL akan memuat sebuah rekapan absen yang datanya diambil dari database yang telah dibangun. Maka pada Gambar 9 ditunjukkan query yang dipilih untuk menjadi konten dari laporan adalah dari tabel 
vwRekapAbsen yang sebelumnya sudah dibahas dengan tambahan parameter tangggal yang ditampilkan pada Gambar 10

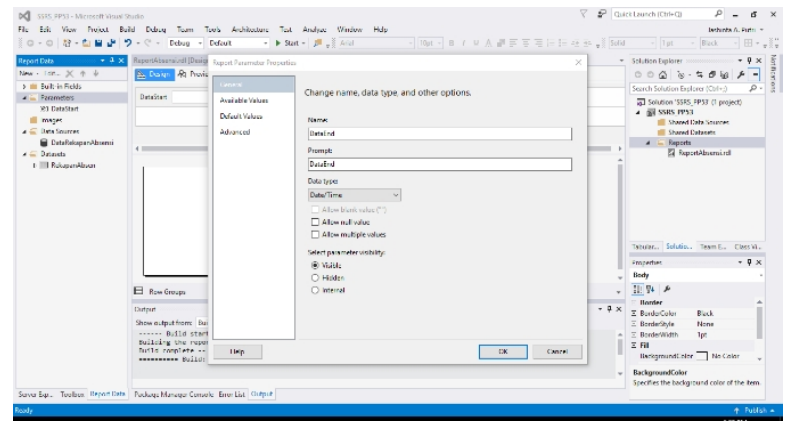

Gbr 10 Konfigurasi Parameter

Selain tabel vwRekapAbsen secara keseluruhan, query yang akan digunakan pula adalah SELECT TOP $3 *$ FROM vwRekapAbsen ORDER BY A DESC. Query tersebut bertujuan untuk menampilkan 3 data pertama dari tabel vwRekapAbsen yang mana memiliki jumlah A (Absen) terbanyak. Query ini nantinya yang akan digunakan sebagai bahan pertimbangan dan analisa bagi para pimpinan instansi untuk melakukan pengawasan kedisiplinan kehadiran dari pegawai yang dipimpinnya.

Setelah semua konfigurasi diselesaikan, maka RDL siap untuk didisain. Pada layout RDL terdapat banyak pilihan jenis visualisasi yang dapat digunakan untuk menjadi konten dari sebuah laporan antara lain tabel, chart, databar, dan sebagainya seperti yang ditampilkan pada Gambar 11 .

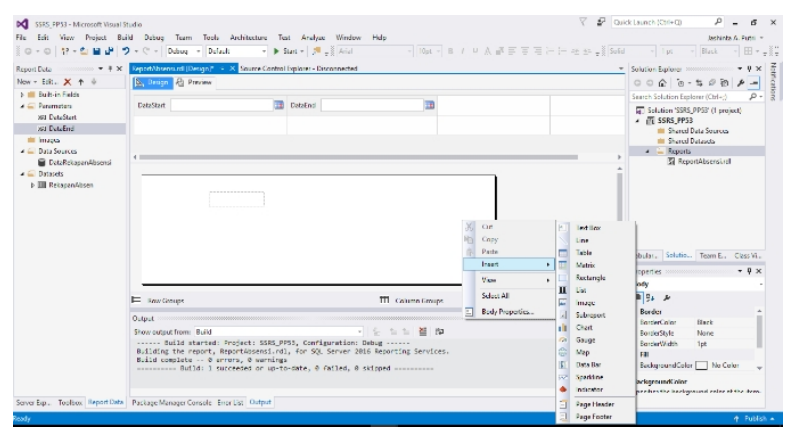

Gbr 11 Blank Layout RDL

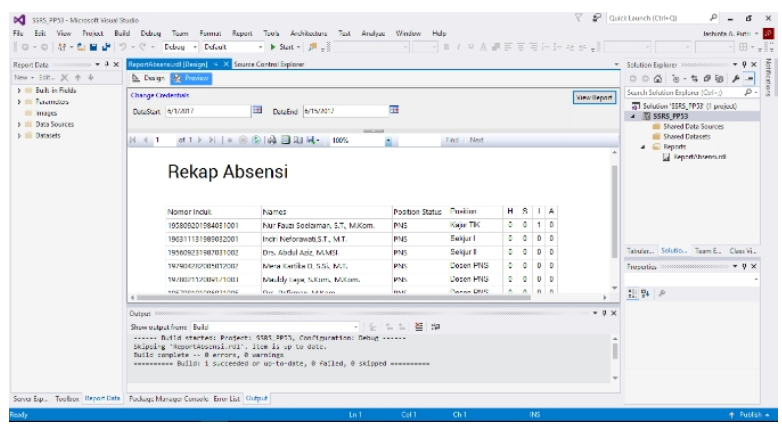

Gbr 12 Preview Layout Laporan
Pada Gambar 12 ditampilkan preview layout dari RDL yang akan di-deploy nantinya. RDL telah selesai dirancang, akan tetapi proses realisasi dari implementasi reporting service menggunakan SSRS belumlah selesai. Masih ada beberapa tahapan yang harus dilalui. Langkah selanjutnya adalah bagian terpenting dalam reporting service menggunakan SSRS, yaitu mengkonfigurasi SSRS. Konfigurasi SSRS sangatlah mudah seperti yang ditampilkan pada Gambar 13, cukup memasukan nama server, serta memiih report server instance yang maka SSRS telah aktif. Konfigurasi penting karena jika SSRS terkonenksi maka reporting service tidak akan berjalan.

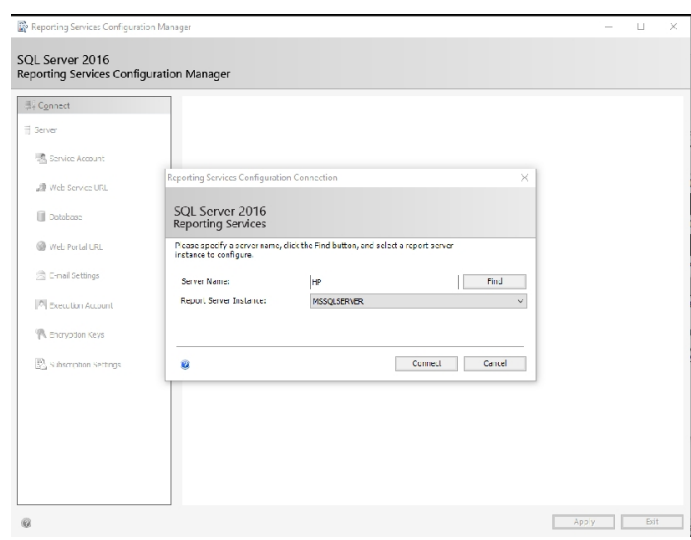

Gbr 13 Konfigurasi SSRS

Setelah mengaktifkan koneksi SSRS, maka langkah selanjutnya adalah kembali ke aplikasi Visual Studio untuk mengkonfigurasi properties dari proyek pelaporan yang telah dirancang. Pada konfigurasi tesebut terdapat baris TargetServerURL yang mana merupakan link untuk menampilkan laporan yang telah dirancang. Selain itu pada konfigurasi properties terdapat pula baris TargetServerVersion untuk memilih versi SQL Server mana yang digunakan pada saat mengkonfigurasi koneksi SSRS. Konfigurasi properties tersebtu ditampilkan pada Gambar 14

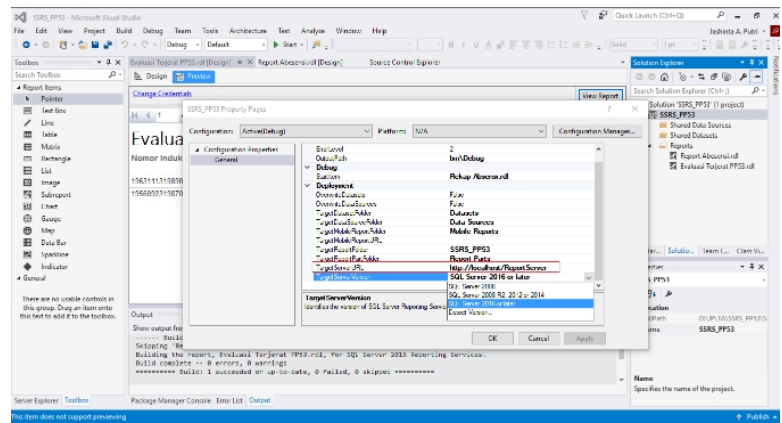

Gbr 14 Konfigurasi Properties

Langkah terakhir adalah deploy proyek laporan yang telah dirancang. Deploy ini bertujuan untuk mempublikasikan laporan-laporan tersebut ke dalam dashboard SSRS dalam bentuk halaman aspx. Cara untuk 
deploy proyek report ini sangatlah mudah yaitu dengan mengklik kanan proyek Reporting Server Project lalu klik Deploy. Untuk melihat hasil dari laporan yang telah dirancang sebelumnya, cukup masukan link dari TargetServerURL pada konfigurasi properties sebelumnya ke dalam web browser dengan administrator authorization. Hal ini dikarenakan SSRS bersifat krusial sehingga hanya dengan administrator authorization baru dapat masuk ke halaman aspx berupa dashboard seperti yang ditampilkan pada Gambar 15 dan Gambar 16.

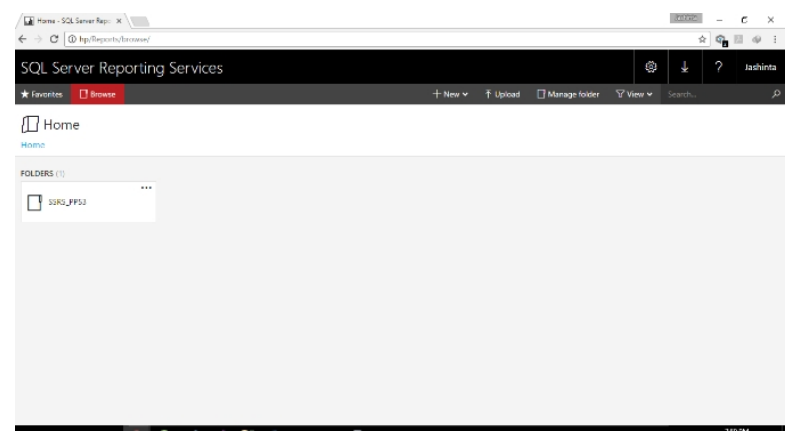

Gbr 15 Dashboard SSRS

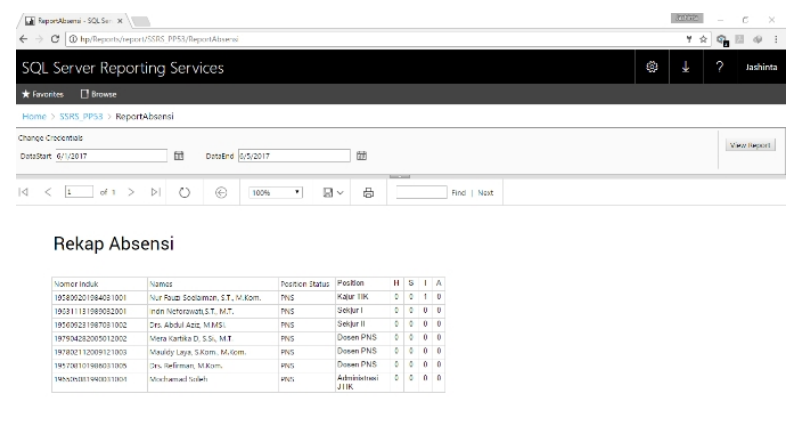

Gbr 16 Laporan dari RDL bentuk Tabel

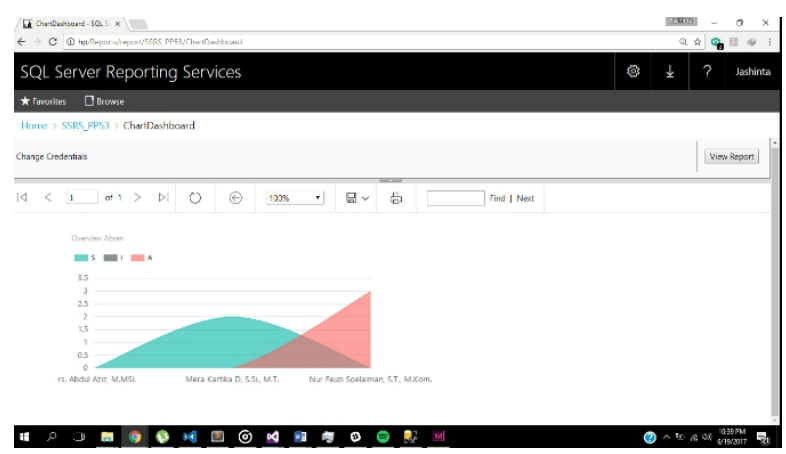

Gbr 17 Laporan dari RDL bentuk Chart

Pada Gambar 16 dan Gambar 17 ditunjukan bahwa laporan yang berada pada Dashboard SSRS memiliki banyak fitur. Fitur-fitur pelaporan antara lain export files, print, search, and navigator/pagination.

\section{PENUTUP}

Setelah melakukan pengimplementasian reporting service dengan menggunakan SSRS pada aplikasi absensi maka dapat ditarik kesimpulan bahwa dengan adanya reporting service SSRS sebagai platform pelaporan mempermudah dalam merekap, menyimpan, mendistribusikan, dan juga dapat menjadi bahan analisa dalam perencanaan bisnis. Dengan menggunakan reporting service SSRS maka kemungkinan teradinya kesalahan dalam perekapan absensi akan sangat kecil. Selain itu sekuritas reporting service menggunakan SSRS sangatlah terjaga. Karena peggunaan reporting service SSRS harus dengan administrator authorization untuk dapat menjalakannya.

Akan lebih baik jika dapat di integrasikan dengan Microsoft BI tools lainnya yaitu Integration Service (SSIS) dan Analytic Service (SSAS) sehingga tidak hanya digunakan untuk aplikasi absensi serta perekapan palaporan, namun juga dapat digunakan sebagai analisis kebutuhan bisnis (BI) secara keseluruhan.

\section{UCAPAN TERIMA KASIH}

Terima kasih disampaikan kepada Risanuri Hidayat yang telah meluangkan waktu untuk membuat template ini. Dan terimakasih sekali untuk tim editor dan semua yang berkontribusi pada jurnal ini.

\section{REFERENSI}

[1] Peraturan Pemerintah Republik Indonesia Nomor 53 Tahun 2010 Disiplin Pegawai Negeri Sipil.

[2] Hadari, Nanawi. Ilmu Administrasi. Jakarta: Ghalia Indonesia, 1994.

[3] Sparkman, M., Saxton, A., Mansfield, C., dan Guyer, C. "What is SQL Server Reporting Services (SSRS)?" Diakses 23 Mei 2017. https://docs.microsoft.com/en-us/sql/reporting-services/create-deployand-manage-mobile-and-paginated-reports.

[4] Departemen Pendidikan Nasional. Kamus Besar Bahasa Indonesia Pusat Bahasa Edisi Keempat. Jakarta: PT. Gramedia Pustaka Utama, 2008 .

[5] Budihardjo, M. Panduan Praktis Penilaian Kinerja Karyawan. Jakarta: Raih Asa Sukses, 2015.

[6] Ben-Gan, Itzik. Microsoft ${ }^{\circledR}$ SQL Server ${ }^{\circledR} 2012$ T-SQL Fundamentals. California: O'Reilly Media, Inc, 2012.

[7] Leblanc, P. Microsoft SQL Server 2012 Step by Step. California: O'Reilly Media, Inc, 2013.

[8] Bakhshi, Soheil. "SSRS 2016 and Power BI". Diakses 23 Mei 2017 http://biinsight.com/ssrs-2016-power-bi/.

[9] Vasilecas, O., Caplinskas, A., Wojtkowski, G., Wojtkowski, W., Zupancic, J., dan Wrycza S. Information Systems Development: Advances in Theory, Practice, and Education. New York: Springer Science \& Business Media, 2005. 